\title{
First molecular and serological detection of Epizootic Hemorrhagic Disease virus in white tailed deer (Odocoileus virginianus) from Tamaulipas, Mexico
}

\author{
[Primeira detecção molecular e sorológica do vírus Doença Hemorrágica Epizoótica em veados \\ de cauda branca (Odocoileus virginianus) de Tamaulipas, Mexico ] \\ J.O. Merino ${ }^{1}$, De la Cruz. NI ${ }^{1}$, G. Galvan ${ }^{1}$, A.P. De León ${ }^{2}$, Burnes. ${ }^{1}$. \\ ${ }^{1}$ Universidad Autónoma de Tamaulipas - Victoria - Tamaulipas, Mexico \\ ${ }^{2}$ USDA-ARS Knipling-Bushland U.S. Livestock Insects Research Laboratory and \\ Veterinary Pest Genomics Center, Kerrville, Texas, U.S.A.
}

\begin{abstract}
Epizootic hemorrhagic disease viruses (EHDV) are dsRNA arboviruses transmitted by biting midges of the genus Culicoides that cause disease in domestic and wild ruminants. Epizootic hemorrhagic disease (EHD) is considered the most important infectious disease of white tailed deer (WTD) in North America, some studies in Northeast Mexico reported EHDV-seropositive WTD and EHDV-infected Culicoides vectors. The increasing population of WTD that share habitat with livestock in Northeast México highlights the importance of EHD for the livestock industry in the transboundary region with the U.S. One hundred and twenty two samples from WTD in Tamaulipas state, Mexico were tested by ELISA and RT-PCR for EHDV antibodies and nucleic acid, respectively. Twelve animals were seropositive to ELISA and eleven animals were positive by RT-PCR. This is the first report of EHDV nucleic acid detection in WTD from Mexico. It is hypothesized that applying the transboundary disease approach to interdisciplinary research will help fill knowledge gaps, which could help develop countermeasures to mitigate the threat of EHDV infection in wildlife and livestock along the U.S.-Mexico border.
\end{abstract}

Keywords: deer, detection, EHDV, RT-PCR, serology

\section{RESUMO}

Virus da doença hemorrágica epizoótica (EHDV) são arbovírus dsRNA transmitidos por mordidas do genus Culicoides que causam doenças em ruminantes domésticos e selvagens. Doença hemorrágica epizoótica (EHD) é considerada uma das doenças infecciosas mais importantes dos veados de cauda branca (WTD) na América do Norte. Alguns estudos no Nordeste do México relatam soropositividade para EHDV em WTD e vetores Culicoides infectados com EHDV. A crescente população de WTD que compartilham hábitats com pecuária no Nordeste do México realçam a importância de EHD para a indústria pecuária na região de fronteira com os Estados Unidos. Cento e vinte duas amostras de WTD no estado de Tamaulipas, Mexico, foram testados por ELISA e RT-PCR para anticorpos e ácido nucleico de EHDV, respectivamente. Esse é o primeiro relato de deteç̧ão de ácido nucleico de EHDV em WTD do México. A hipótese é de que a aplicação de uma resposta transfronteira e pesquisa interdisciplinar ajudará a preencher lacunas de conhecimento levando a medidas reativas para mitigar a ameaça de infecção por EHDV na pecuária e animais selvagens na fronteira entre os Estados Unidos e o Mexico.

Palavra-chaves: veado, detecção, EHDV, RT-PCR, sorologia

\section{INTRODUCTION}

Epizootic hemorrhagic disease viruses (EHDV) are dsRNA orbiviruses transmitted by biting midges of the genus Culicoides that cause disease in domestic and wild ruminants (Savini

Recebido em 26 de abril de 2017

Aceito em 5 de março de 2018

E-mail: mero840125@hotmail.com et al., 2011; Maclachlan et al., 2015). Although originally reported in north America affecting white-tailed deer (WTD), Odocoileus virginianus (Shope et al., 1960), Epizootic Hemorrhagic Disease (EHD) is now considered an emerging and re-emerging Culicoides-borne animal disease affecting livestock in several parts of the world 
(Temizel et al., 2009; Kedmi et al., 2011; Toye et al., 2013; Cêtre-Sossah et al., 2014). In brazil EHDV infection was shownto be lethal to grey crocket deer Mazama gouazoubira (Favero et al., 2013). There are seven EHDV serotypes recognized worldwide (Ruder et al., 2015a), and EHD is considered one of the most important infectious diseases of WTD (Stallknecht et al., 2015). However, recent epidemiological shifts have increased the concern of livestock producers in North America for EHD (Breard et al., 2013; McVey et al., 2015; Stevens et al., 2015). Despite advancements in our understanding of EHD and its diagnosis (Wilson et al., 2015), there are gaps in our knowledge of aspect related to its epidemiology in North America (Ruder et al., 2015a). Serotypes EHDV1 and EHDV-2 were known to be endemic, and in 2006 EHDV-6 was isolated from WTD in North America (Allison et al., 2010; Maclachlan and Guthrie, 2010). The significance of the emergence of EHDV-6 to livestock and wild ruminant population remains to be determined (Stallknecht et al., 2015). Additionally, Culicoides-host-EHDV interactions and environmental factors influencing EHD outbreaks remain to be fully understood in some parts of North America (Pfannenstiel et al., 2015), including the transboundary region encompassing the Mexico-US border.

The transboudary region comprising the MexicoUS border along the Rio Grande lies within a disease hotspot (Esteve-Gassent et al., 2014). An abundant WTD population on both sides of the border represents a risk for the emergence and re-emergence of animal and zoonotic diseases, several of which are arthropod-borne like EHD (Cantu et al., 2008; Medrano et al., 2012; Pérez de León et al., 2012; Feria-Arroyo et al., 2014). Seroepidemiological data indicated EDHV circulate among WTD in Texas and parts of Mexico (Wilhelm and Trainer, 1966; Stallknecht et al., 1996; Martinez et al., 1999). Known and suspected Culicoides vectors of EHDV are present in the south Texas - Northeastern Mexico transboundary region (Smith and Stallknecht, 1996; Sánchez-Rojas and Gallina, 2007; Huerta et al., 2012; Lozano-Rendón et al., 2015).

Our group investigated suspected EHD cases in WTD that occurred in the state of Tamaulipas, Mexico where cattle and WTD co-habit pastures.
The results of our serological and molecular studies documenting the infection of WTD with EHDV are reported here. These findings are discussed in the context of the need to adapt current practices to minimize the risk of EHD morbidity and mortality in livestock and WTD populations.

\section{MATERIAL AND METHODS}

This study was approved by the Animal Ethics committee of the Faculty of Veterinary Medicine at the University of Tamaulipas, México (Approval number CBBA-1520). Blood samples from WTD were obtained according to good animal handling practices and procedures set forth by the same Animal Ethics committee, as well as the various samples in forensic postmortem study in the field.

Blood samples were taken from 122 WTD that were suspected of being afflicted by EHD in 9 municipalities of Tamaulipas state, Mexico. Ninety-five samples were collected from WTD residing in farms, and 27 samples were collected from WTD that were either harvested or found dead in the wild. Two samples were taken from each animal using sterile vacutainer blood collection tubes, blood for RNA extraction was obtained in a tube containing EDTA as the anticoagulant and a tube without anticoagulant was used to obtain serum from the blood sample. Both tubes were maintained at $4^{\circ} \mathrm{C}$ until arrival at the laboratory. Serum was then separated by centrifugation and stored at $-20^{\circ} \mathrm{C}$.

Samples of WTD liver, heart and spleen were obtained from suspected cases of EHD for gross pathology and histopathological analyses. Histological procedures were followed to provide good quality sections for light microscopic evaluation of animal tissue changes associated with EHD (Ruder et al., 2016). Tissues were fixed with neutral formalin $10 \%$, embedded in paraffin, and then manually sectioned with a microtome to obtain 4-5 $\mu \mathrm{m}$ thick paraffin sections. Dewaxed sections were stained with hematoxylin and eosin (H\&E).

Total RNA was extracted from WTD blood samples using a commercially available kit following manufacturer's recommendations (Trizol $^{\circledR}$ RNA purification Kit; Invitrogen carlbad, CA, USA). The final RNA pellet was 
resuspended in $50 \mu 1$ of nuclease free water. RNA concentration and purity were determined by measuring the optical density at $260 \mathrm{~nm}$ in a JENWAY 6405UV/VIS spectrophotometer and the extracted RNA stored at $-80^{\circ} \mathrm{C}$ until use.

Serum samples were assayed for antibody titers determined by antigen-specific indirect ELISA using the EHDV Antibody Assay Kit (Bioo Scientific, Austin, TX). The cut-off for positive samples was set at an OD value of 0.4 at a 1:100 dilution of the serum sample following the manufacturer's instructions.

Total RNA was used for RT-PCR that was performed in a final volume of $50 \mu \mathrm{l}$ using a commercial kit according to manufacturer's instructions (Access RT-PCR system; Promega, Madison, WI, USA). The oligonucleotide primers used were EHDVFW 5'ACWGGVATCATGTTTGAGCT and EHDVRV 5'-TTCATAACCGCACCTTCATC$3^{\prime}$, which amplify a 105 bp product of the NS1 gene encoded in EHDV genome segment 6 (Clavijo et al. 2010). An Applied Biosystems 2720 Thermal Cycler was used following the manufacturer's recommendations to run the RTPCR under these conditions: $45^{\circ} \mathrm{C}$ for $40 \mathrm{~min}$ and $95^{\circ} \mathrm{C}$ for $10 \mathrm{~min} ; 35$ amplification cycles with denaturation at $95^{\circ} \mathrm{C}$ for $15 \mathrm{~s}$, annealing at $50^{\circ} \mathrm{C}$ for $30 \mathrm{~s}$, extension at $72^{\circ} \mathrm{C}$ for $90 \mathrm{~s}$; and finally, an extension at $72^{\circ} \mathrm{C}$ for $3 \mathrm{~min}$ with termination of the reaction at $4^{\circ} \mathrm{C}$. The product was stored at $-20^{\circ} \mathrm{C}$ until further analysis.

RT-PCR products were loaded in a $1.5 \%$ agarose gel, for electrophoresis. Subsequently, the gel was stained using Diamond ${ }^{\mathrm{TM}}$ Nucleic Acid Dye (Promega, Madison, WI, USA), visualized, and photographed under ultraviolet light using an ENDURO GDS gel documentation system (LABNET).

\section{RESULTS}

Table 1 summarizes the results of the serological analysis conducted on WTD from 9 municipalities in Tamaulipas, México. Antibodies against EHDV were detected in $9.8 \%$ $(12 / 122)$ of the WTD tested. Seventy-five \% of the seropositive WTD were females (9/12), and $25 \%$ males (3/12). Females composed $75 \%$ of the total number (92/112) of WTD sampled; three samples were not included as seropositive because they had antibodies titers very close to the cut off value.

Seropositive cases appeared to cluster in the northern municipalities of Nuevo Laredo and Mendez. The municipality of Nuevo Laredo, which had the largest number of seropositive samples (7/12), borders south Texas. In general, WTD from municipalities located in the southern part of the state were seronegative.

Table 1. Epizootic hemorrhagic disease virus serological and molecular test results for white-tailed deer from nine municipalities in the state of Tamaulipas, Mexico

\begin{tabular}{cccccc} 
Municipality & $\begin{array}{c}\text { Number of } \\
\text { samples }\end{array}$ & $\begin{array}{c}\text { Number of } \\
\text { Males }\end{array}$ & $\begin{array}{c}\text { Number of } \\
\text { females }\end{array}$ & $\begin{array}{c}\text { ELISA } \\
\text { Positives }\end{array}$ & $\begin{array}{c}\text { RT-PCR } \\
\text { Positives }\end{array}$ \\
\hline Burgos & 4 & 4 & 0 & 0 & 0 \\
Cruillas & 9 & 9 & 0 & 1 & 1 \\
Jiménez & 1 & 1 & 0 & 0 & 0 \\
Llera & 2 & 1 & 1 & 0 & 0 \\
Mendez & 34 & 0 & 34 & 2 & 5 \\
Nuevo Laredo & 58 & 3 & 55 & 7 & 0 \\
Padilla & 1 & 1 & 0 & 0 & 0 \\
San Carlos & 1 & 0 & 1 & 0 & 0 \\
Victoria & 12 & 11 & 1 & 2 & 9 \\
Total & 122 & 30 & 92 & 12 &
\end{tabular}

Seven $\%$ of the WTD sampled were positive by RT-PCR (9/122) (Table 1). The majority (89\%) of the PCR-positive samples were from females (8/9). Only one male from the municipality of Cruillas, which is located in the north-central part of the state, was PCR positive. PCR amplicons with a molecular weight of $105 \mathrm{bp}$ were considered positive (Figure 1). However, this molecular assay does not identify the serotype of the EHDV detected. 
Merino et al.

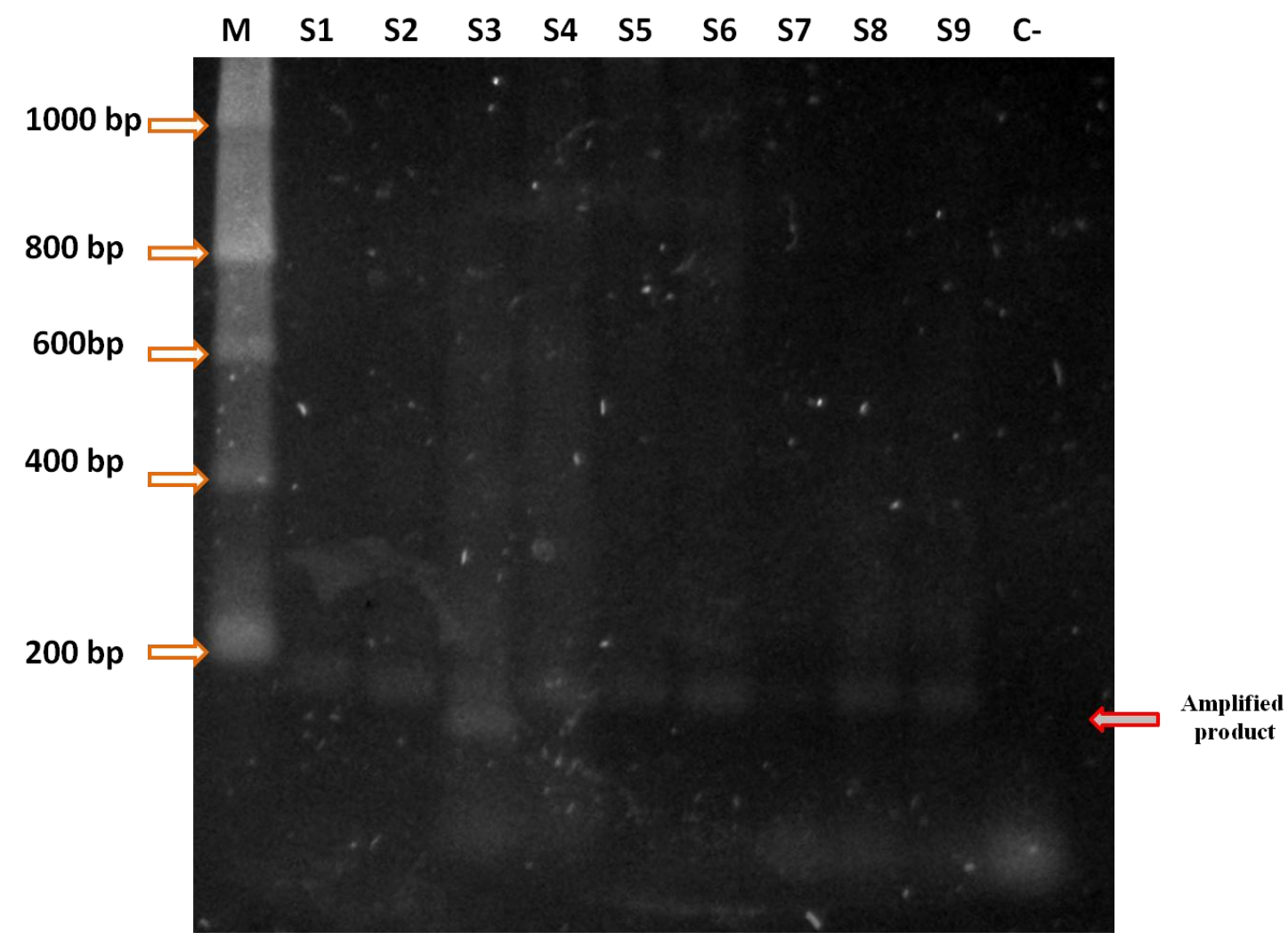

Figure 1. Detection of epizootic hemorrhagic disease virus nucleic acid in white-tailed deer from Tamaulipas state, Mexico by RT-PCR. Photograph of agarose gel electrophoresis at $1.5 \%$ showing in each lane (M): $1 \mathrm{~kb}$ bases pair ladder; S2-S9: samples positive for 105bp fragment produced using primers to amplify segment of EHDV non-structural protein 1; C: negative control (Double distilled water).

Sixteen $\%$ of the WTD sampled (20/122) were positive for EHDV by ELISA, PCR, or both (Table 2). Fifty-five\% of the PCR positive samples (5/9) were from group of 3.5-yr old female WTD in Mendez municipality, which is in the northeast sector of the state close to U.S border. One of those female WTD (sample ID: 49) in Mendez municipality was ELISA and PCR positive.

Significant gross pathology was noted in the liver, heart, and lungs (Figure 2). These lesions were reflected microscopically as evidence of widespread microvascular damage, which is consistent with the effects of replication in endothelium. Histopathological findings in the liver included foci of mononuclear inflammatory cell infiltrate, which was accompanied by mild fatty degenerative change with formation of thin vacuoles (Figure 3). Additionally, liver sections in which diffuse moderate congestion was observed corresponded histologically with mild dissociation of hepatic cords, multifocal hemorrhages, and discrete inflammatory infiltrate. Widespread hemorrhage with edema and endothelial damage was observed in the myocardium (Figure 4). Varying degrees of myofibrillar distension, with myocardial polymorphonuclear cell infiltration were also observed in these sections. 
First molecular...

Table 2. Epizootic hemorrhagic disease virus positivity by ELISA or RT-PCR test for white-tailed deer from the state of Tamaulipas Mexico

\begin{tabular}{cccccc}
\hline Sample ID & Municipality & ELISA Result & RT-PCR result & $\begin{array}{c}\text { Deer age } \\
\text { (Years) }\end{array}$ & Sex \\
\hline D15 & Victoria & + & - & 4 & Male \\
D18 & Victoria & + & - & 6 & Male \\
D22 & Nuevo Laredo & + & - & 1.5 & Female \\
D30 & Nuevo Laredo & + & - & 1.5 & Female \\
D39 & Nuevo Laredo & + & - & 3.5 & Female \\
D44 & Mendez & - & + & 3.5 & Female \\
D45 & Mendez & + & - & 3.5 & Female \\
D49* & Mendez & + & + & 3.5 & Female \\
D65 & Mendez & - & + & 3.5 & Female \\
D66 & Mendez & - & + & 3.5 & Female \\
D71 & Mendez & - & + & 3.5 & Female \\
D77 & Cruillas & + & - & 4.5 & Male \\
D79 & Cruillas & - & + & 4.5 & Male \\
D89 & Nuevo Laredo & + & - & 1.5 & Female \\
D92 & Nuevo Laredo & + & - & 4.5 & Female \\
D99 & Nuevo Laredo & + & + & 1.5 & Female \\
D109 & Nuevo Laredo & - & + & 1.5 & Female \\
D112 & Nuevo Laredo & - & + & 1.5 & Female \\
D114 & Nuevo Laredo & - & - & 1.5 & Female \\
D120 & Nuevo Laredo & + & & 1.5 & Female \\
\hline
\end{tabular}

*Single white-tailed deer that was ELISA and RT-PCR positive.

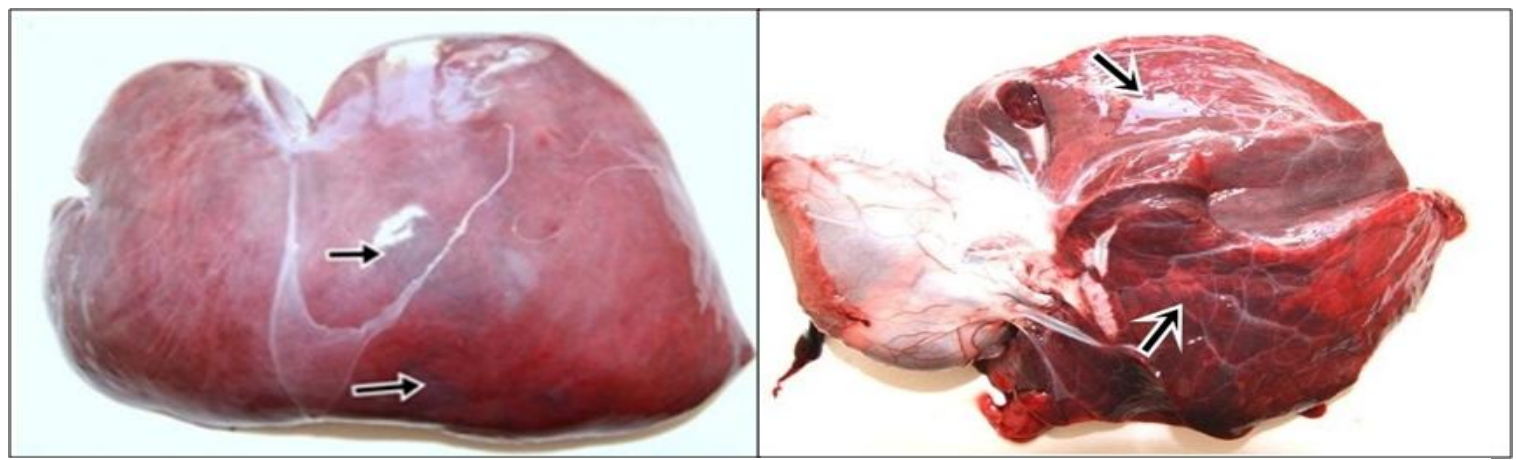

Figure 2. Deer with EHD had liver (A) with severe blood congestion and focal hemorrhages (arrows), which were accompanied by severe blood congestion and hemorrhages (other arrows) in the lungs (B), and multifocal epicardial hemorrhages and moderate edema (arrow head).

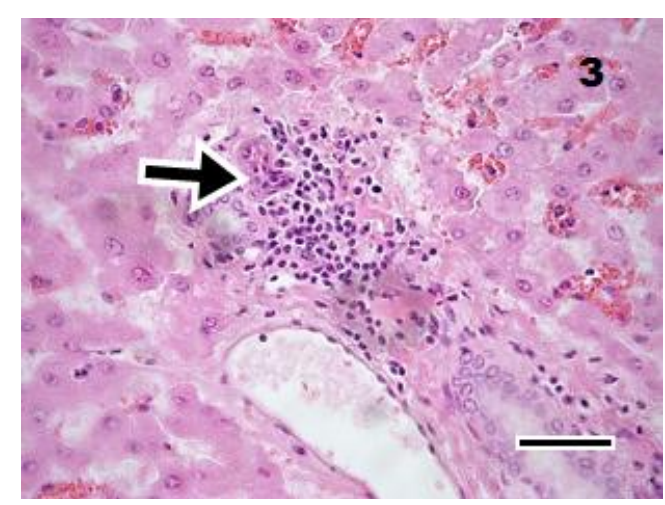

Figure 3. Histopathological analysis of the liver reveled foci of mononuclear inflammatory cell infiltrate (arrow), and mild fatty degenerative change noted in formation of thin vacuoles. $\mathrm{H} \& \mathrm{E}$ staining, Obj. 40x Ocul 10/26. Bar=10 microns. 

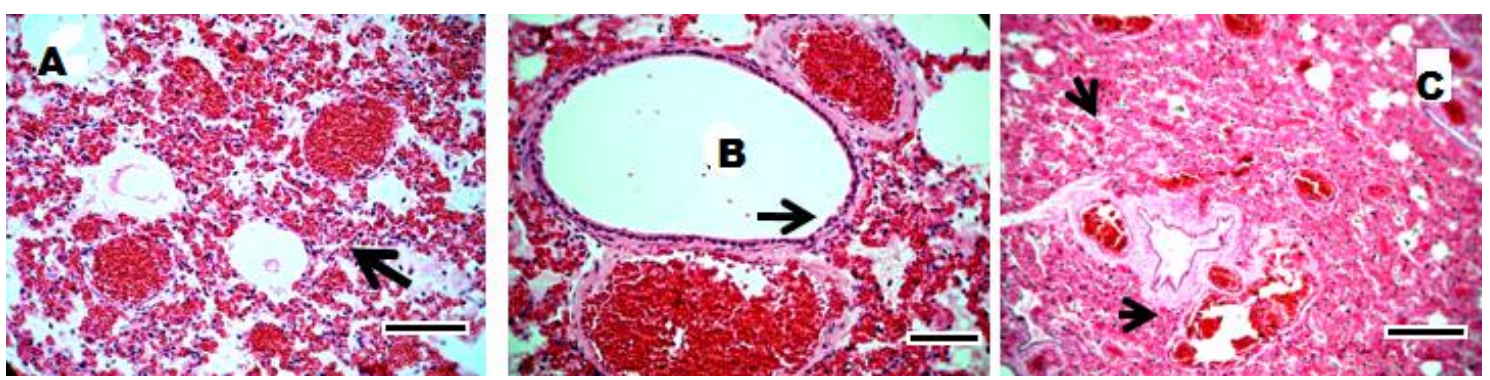

Figure 4. A, B, C. in which the presence of severe bleeding (A, B, C) moderate diffuse edema, blood congestion, severe endothelial damage is observed mild inflammatory infiltrate and discreet. H \& E staining Obj. 40x Ocul 10/26, Bar=10 microns.

\section{DISCUSSION}

This study documented for the first time the detection of EHDV RNA from WTD in Mexico. A previous study reported EHDV nucleic acid amplification from Culicoides vectors in Northeast Mexico (Lozano-Rendón et al., 2015). These findings are in agreement with results indicating that EHDV are endemic in parts of Mexico.

EHDV reactive antibodies in WTD were reported in Northeast Mexico, including the state of Tamaulipas (Martinez et al., 1999). Big horn sheep (Ovis canadiensis) where shown to be exposed to EHDV in the state of Baja California, which is part of another region in México where known Culicoides vectors exist (Sánchez-Rojas and Rojas-Martínez, 2007; Huerta et al., 2012). Serological and nucleic acid assays are important techniques to detect EHDV (Manual..., 2014). Nucleic acid detection in one of the criteria required for EHDV diagnosis. The RT-PCR approach we took is regarded as a suitable method to assess the prevalence of EHDV infection in susceptible animals like WTD (Clavijo et al., 2010; Manual..., 2014) ELISA test like the one used in our study can be used for diagnostic and surveillance research. The detection of specific antibodies indicates exposure to EHDV (Wilson et al., 2015) but the serological test results reported here do not confirm presence of viral antigen in WTD. If WTD do not succumb to EHD, seroconversion occurs around 10 days post-infection (Ruder et al., 2015b). The results of serological and molecular assays suggest that in addition to WTD, livestock is also at risk of EHDV infection in northeast Mexico.
Taking into account previous studies and the results presented here on EHD in WTD from Texas and Northeast Mexico, it is hypothesized that applying the transboundary disease approach to research will help fill knowledge gaps on this economically important disease of wildlife and livestock (Esteve-Gassent et al., 2014; Maan et al., 2016). The serodiagnosis of EHD in WTD occurred in Texas not too long after the disease was first reported in the U.S. in the 1950s (Shope et al., 1960; Wilhelm and Trainer, 1966). The apparent endemicity of EHDV in Texas and Northeast Mexico seems to be associated with differences in innate resistance to infection between WTD populations, which may influence EHD epidemiology (Stallknecht et al., 1996; Martinez et al., 1999; Gaydos et al., 2002). However, EHDV virulence, WTD herd immunity, and Culicoides vector competency, among other components of this economically important disease system, remain to be fully understood for the U.S.-Mexico transboundary region.

As an arthropod-borne disease, the epidemiology of EHD is influenced by climatic factors that determine the abundance of infected Culicoides vectors, which is a risk factor for EHD outbreaks in WTD and livestock (Lozano-Rendón et al., 2015; Stallknecht et al., 2015; Stevens et al., 2015). Winds are a risk factor for the emergence and re-emergence of EHDV infection in WTD and livestock (Sellers and Maarouf, 1991; Kedmi et al., 2010). However, the movement of viremic livestock has been suggested to be a pathway for the emergence of exotic EHDV in North America (Allison et al., 2012).

In this study we sampled free-ranging and captive WTD, Although the susceptibility to EHDV can vary between subspecies of WTD 
(Gaydos et al., 2002) a protracted EHD outbreak in the U.S. in 2012 apparently affected captive and free-ranging WTD equally (Stevens et al., 2015). However, the management of caprive WTD facilitates the detection of lethaly associated with an EHD outbreak in particular area. Mortality is a risk for captive WTD when kept in the same premises with other ungulate species that undergo mild infection, which could also serve as a source of EHDV (Nol et al., 2010). Therefore, the presence of EHD can have several implications for the livestock industry and wildlife health (Allison et al., 2010; CêtreSossah et al., 2014; Stevens et al., 2015).

Mexico falls within the predicted global range of EHDV between latitudes $35^{\circ} \mathrm{S}$ and $49^{\circ} \mathrm{N}$ (McVey et al., 2015). But, Savini et al. (2011) reported the infection status of Mexico as unknown. Together with previous results, this report documenting the detection of EHDV RNA in WTD from Tamaulipas state support the hypothesis that EHDV are endemic in the Northeast Mexico-US transboundary region. It appears that, like in the U.S., addressing knowledge gaps through interdisciplinary research will help develop countermeasures (Lozano-Rendón et al., 2015; Pfannenstiel et al., 2015; Ruder et al., 2015b), which could mitigate the threat of EHDV infection on wildlife and livestock in Mexico.

\section{CONCLUSIONS}

Results reported in this study documented for the first time the detection of EHDV RNA in deer from the northeast area of Mexico. According to the World Organization for animal health the technique reverse transcriptase polymerase chain reaction (RT-PCR) technique can be used for laboratory diagnosis, but the results may be difficult to interpret because EHDV nucleic acid may persist in blood of deer much longer than infectious virus. Mexico is located within the geographic range of EHDV and the detection of nucleic acids in the insect was reported in northeast Mexico. Thus, the results reported here support the presence of EHDV in Mexico, which highlights the need for further research to develop EHD countermeasures to protect livestock and wildlife health. All authors declare that there are no financial or other relationships that might lead to a conflict of interest. All authors have seen and approved the manuscript and have contributed significantly to the work.

\section{ACKNOWLEDGMENTS}

This research was supported by project DSA/103.5/14/7505 sponsored by the professional development program for teachers PRODEP. We thank to Rachel Kenneil and the parasitology and molecular biology laboratory staff of the FMVZ. University of Tamaulipas, Mexico. USDA is an equal opportunity provider and employer.

\section{REFERENCE}

ALLISON, A.B.; GOEKJIAN, V.H.; POTGIETER, A.C. et al. Detection of a novel reassortant epizootic hemorrhagic disease virus (EHDV) in the USA containing RNA segments derived from both exotic (EHDV-6) and endemic (EHDV-2) serotypes. J. Gen. Virol., v.91, p.430439, 2010.

ALLISON, A.B.; HOLMES, E.C.; POTGIETER, A.C. et al. Segmental configuration and putative origin of the reassortant orbivirus, epizootic hemorrhagic disease virus serotype 6, strain Indiana. Virology, v.424, p.67-75, 2012.

BREARD, E.; BELBIS, G.; VIAROUGE, C. et al. Epizootic hemorrhagic disease virus serotype 6 experimentation on adult cattle. Res. Vet. Sci., v.95, p.794-798, 2013.

CANTU, A.; ORTEGA-S, J.A.; MOSQUEDA, J. et al. Prevalence of infectious agents in freeranging white-tailed deer in northeastern Mexico. J. Wildl. Dis., v.44, p.1002-1007, 2008.

CÊTRE-SOSSAH, C.; ROGER, M.; SAILLEAU, C. et al. Epizootic haemorrhagic disease virus in Reunion Island: evidence for the circulation of a new serotype and associated risk factors. Vet. Microbiol., v.170, p.383-390, 2014.

CLAVIJO, A.; SUN, F.; LESTER, T.; JASPERSON, D.C.; WILSON, W.C. An improved real-time polymerase chain reaction for the simultaneous detection of all serotypes of Epizootic hemorrhagic disease virus. J. Vet. Diagn. Invest., v.22, p.588-593, 2010.

ESTEVE-GASSENT, M.D.; PÉREZ DE LEÓN, A.A.; ROMERO-SALAS, D. et al. Pathogenic landscape of transboundary zoonotic diseases in the Mexico-US border along the Rio Grande. Front. Public Health, v.2, p.1-23, 2014. 
FAVERO, C.M.; MATOS, A.C.; CAMPOS, F.S. et al. Epizootic hemorrhagic disease in brocket deer, Brazil. Emerg. Infect. Dis., v.19, p.346-348, 2013.

FERIA-ARROYO, T.P.; CASTROARELLANO, I.; GORDILLO-PEREZ, G. et al. Implications of climate change on the distribution of the tick vector Ixodes scapularis and risk for Lyme disease in the Texas-Mexico transboundary region. Parasit. Vectors, v.7, p.116, 2014.

GAYDOS, J.K.; DAVIDSON, W.R.; ELVINGER, F. et al. Innate resistance to epizootic hemorrhagic disease in white-tailed deer. J. Wildl. Dis., v.38, p.713-719, 2002.

HUERTA, H.; RODRÍGUEZ, A.M.; GROGAN, W.; AND IBÁÑEZ-BERNAL, S. New records of biting midges of the genus Culicoides Latreille from Mexico (Diptera: Ceratopogonidae). Insecta Mundi, v.211, p.1-20, 2012.

KEDMI, M.; GALON, N.; HERZIGER, Y. et al. Comparison of the epidemiology of epizootic haemorrhagic disease and bluetongue viruses in dairy cattle in Israel. Vet. J., v.190, p.77-83, 2011.

KEDMI, M.; HERZIGER, Y.; GALON, N. et al. The association of winds with the spread of EHDV in dairy cattle in Israel during an outbreak in 2006. Prev. Vet. Med., v.96, p.152-60, 2010.

LOZANO-RENDÓN, J.A.; CONTRERASBALDERAS, A.J.; FERNÁNDEZ-SALAS, I.; ZARATE-RAMOS, J.J.; AVALOS-RAMÍREZ, R. Molecular detection of bluetongue virus (BTV) and epizootic hemorrhagic disease virus (EHDV) in captured Culicoides spp. in the northeastern regions of Mexico. Afr. J. Microbiol. Res., v.9, p.2218-2224, 2015.

MAAN, N.S.; MAAN, S.; POTGIETER, A.C. et al. Development of Real-Time RT-PCR assays for detection and typing of epizootic haemorrhagic disease virus. Transbound. Emerg. Dis., v.1, p.1-13, 2016.

MACLACHLAN, N.J.; GUTHRIE, A.J. Reemergence of bluetongue, African horse sickness, and other orbivirus diseases. Vet. Res., v.41, p.35. 2010.
MACLACHLAN, N.J.; ZIENTARA, S.; SAVINI, G.; DANIELS, P.W. Epizootic haemorrhagic disease. Rev. Sci. Tech.,v.34, p.341-351, 2015.

MARTINEZ, A.; SALINAS, A.; MARTINEZ, F.; CANTU, A.; MILLER, D.K. Serosurvey for selected disease agents in white-tailed deer from Mexico. J. Wildl. Dis.,v.35, p.799-803, 1999.

McVEY, D.S.; DROLET, B.S.; RUDER, M.G. et al. Orbiviruses: a north American perspective. Vector Borne Zoonotic Dis.,v.15, p.335-338, 2015.

MEDRANO, C.; BOADELLA, M.; BARRIOS, H. et al. Zoonotic pathogens among white-tailed deer, northern Mexico, 2004-2009. Emerg. Infect. Dis., v.18, p.1372-1374, 2012.

NOL, P.; KATO, C.; REEVES, W.K. et al. Epizootic hemorrhagic disease outbreak in a captive facility housing white-tailed deer (Odocoileus virginianus), bison (Bison bison), elk (Cervus elaphus), cattle (Bos taurus), and goats (Capra hircus) in Colorado, U.S.A. J. Zoo. Wildl. Med., v.41, p.510-515, 2010.

MANUAL of diagnostic test and vaccines for terrestrial animals. Paris: OIE, 2014. Available in: <http://wahis2devt.oie.int/fileadmin/Home/fr/Health_standards/ tahm/2.01.04b_EHD.pdf. 2014>. Accessed on 25 Jan. 2017.

PÉREZ DE LEÓN, A.A.; TEEL, P.D.; AUCLAIR, A.N. et al. Integrated strategy for sustainable cattle fever tick eradication in USA is required to mitigate the impact of global change. Front. Physiol., v.3, p.195, 2012.

PFANNENSTIEL, R.S.; MULLENS, B.A.; RUDER, M.G. et al. Management of north American culicoides biting midges: current knowledge and research needs. Vector Borne Zoonotic Dis., v.15, p.374-384, 2015.

RUDER, M.G.; LYSYK, T.J.; STALLKNECHT, D.E. et al. Transmission and epidemiology of bluetongue and epizootic hemorrhagic disease in North America: current perspectives, research gaps, and future directions. Vector Borne Zoonotic Dis., v.15, p.348-363, 2015a 
RUDER, M.G.; STALLKNECHT, D.E.; ALLISON, A.B. et al. Host and potential vector susceptibility to an emerging orbivirus in the United States:Epizootic hemorrhagic disease virus serotype 6. Vet. Pathol., v.53, p.574-584, 2016.

RUDER, M.G.; STALLKNECHT, D.E.; HOWERTH, E.W. et al. Effect of temperature on replication of epizootic hemorrhagic disease viruses in culicoides sonorensis (diptera: ceratopogonidae). J. Med. Entomol., v.52, p.1050-1059, 2015 b.

SÁNCHEZ-ROJAS， G.; GALLINA， S. Metapoblaciones, el reto en la biología de la conservación: el caso del venado bura en el Bolsón. In: (Eds.). Tópicos en sistemática, biogeografía, ecología y conservación de mamíferos. Pachuca, Hidalgo: Ciencia al día, 2007. p.95.

SÁNCHEZ-ROJAS， G.; ROJAS-MARTÍNEZ, A. Tópicos en sistemática biogeografia, ecología y conservación de mamíferos. Pachuca, Hidalgo: UAH. 2007.

SAVINI, G.; AFONSO, A.; MELLOR, P. et al. Epizootic heamorragic disease. Res. Vet. Sci., v.91, p.1-17, 2011.

SELLERS, R.F.; MAAROUF, A.R. Possible introduction of epizootic hemorrhagic disease of deer virus (serotype 2) and bluetongue virus (serotype 11) into British Columbia in 1987 and 1988 by infected Culicoides carried on the wind. Can. J. Vet. Res., v.55, p.367-370, 1991.

SHOPE, R.E.; MACNAMARA, L.G.; MANGOLD, R. A virus-induced epizootic hemorrhagic disease of the virginia white-tailed deer (Odocoileus virginianus). J. Exp. Med., v.111, p.155-170, 1960.
SMITH, K.E.; STALLKNECHT, D.E. Culicoides (Diptera: ceratopogonidae) collected during epizootics of hemorrhagic disease among captive white-tailed deer. J. Med. Entomol., v.33, p.507-510, 1996.

STALLKNECHT, D.E.; ALLISON, A.B.; PARK, A.W. et al. Apparent increase of reported hemorrhagic disease in the midwestern and northeastern USA. J. Wildl. Dis., v.51, p.348$361,2015$.

STALLKNECHT, D.E.; LUTTRELL, M.P.; SMITH, K.E.; NETTLES, V.F. Hemorrhagic disease in white-tailed deer in Texas: a case for enzootic stability. J. Wildl. Dis., v.3, p.695-700, 1996.

STEVENS, G.; MCCLUSKEY, B.; KING, A.; O'HEARN, E.; MAYR, G. Review of the 2012 epizootic hemorrhagic disease outbreak in domestic ruminants in the United States. PLoS One., v.10, p.1-15, 2015.

TEMIZEL, E.M.; YESILBAG, K.; BATTEN, C. et al. Epizootic hemorrhagic disease in cattle, Western Turkey. Emerg. Infect. Dis., v.15, p.317-319, 2009.

TOYE, P.G.; BATTEN, C.A.; KIARA, H. et al. Bluetongue and epizootic haemorrhagic disease virus in local breeds of cattle in Kenya. Res. Vet. Sci., v.94, p.769-773, 2013.

WILHELM, A.R.; TRAINER, D.O. A Serological study of epizootic hemorrhagic disease of deer. J. Wildl. Manag., v.30, p.777$780,1966$.

WILSON, W.C.; DANIELS, P.; OSTLUND, E.N. et al. Diagnostic tools for bluetongue and epizootic hemorrhagic disease viruses applicable to North American veterinary diagnosticians. Vector Borne Zoonotic Dis., v.15, p.364-373, 2015. 